\title{
STUDI KONSERVASI AIR UNTUK PEMANFAATAN AIRTANAH YANG BERKELANJUTAN PADA RECHARGE $A R E A$ LERENG GUNUNGAPI MERAPI KABUPATEN SLEMAN YOGYAKARTA
}

Oleh: Hendro Murtianto*)

\begin{abstract}
Abstrak
Manusia dalam memenuhi kebutuhan hidupnya tidak lepas dari keberadaan air yang merupakan salah satu materi penunjang kehidupan. Berbagai cara dilakukan manusia untuk mendapatkan air bersih, salah satunya adalah dengan mengambil air dari dalam bumi atau bawah permukaan tanah. Cara pengambilan air dari bawah permukaan tanah dirasa menjadi cara yang familiar dan paling banyak dilakukan manusia, karena beberapa alasan utama, yaitu: airtanah mudah untuk didapatkan, relatif bersih karena melalui filterisasi struktur tanah-batuan dan secara ekonomis lebih murah. Sedangkan ketersediaannya sangat tergantung dari tingkat infiltrasi dan perkolasi di daerah tangkapan air (recharge area). Recharge area di Yogyakarta dipengaruhi oleh kondisi fisik lahan di daerah hulu, yaitu daerah lereng Gunungapi Merapi yang merupakan tulang punggung sistem geohidrologi kawasan dataran Jogja dan sekitarnya. Akibat perubahan penggunaan lahan yang terjadi di daerah ini telah menurunkan tingkat infiltrasi sehingga terjadi fluktuasi posisi muka airtanah dataran Jogja, terutama pada saat musim kemarau. Untuk itu, perlu upaya-upaya konservasi dalam rangka pelestariannya dengan memperhatikan tipologi sistem aquifer pada daerah tangkapannya.
\end{abstract}

Kata kunci: Konservasi air, airtanah, "recharge area”.

*) Hendro Murtianto, S.Pd., M.Sc., adalah dosen Jurusan Pendidikan Geografi FPIPS UPI. 


\section{Pendahuluan}

Ketersediaan airtanah dalam bumi tersimpan dalam dua zone, yaitu terdapat di non saturated zone dan saturated zone. Non saturated zone (Zone Aerasi/ Zone tidak jenuh) merupakan sebaran tanah yang sebagian rongga antar partikel tanah diisi oleh udara dan sebagian lagi diisi oleh air. Zona aerasi terdapat mulai dari perakaran tanaman hingga kapilaritas air jenuh. Pada zona ini terdapat soil moisture (kelengasan tanah), air vadose dan air kapiler. Zona ini merupakan zona yang paling berperan dalam bidang pertanian. Ketersediaan airtanah dalam zona ini dinyatakan sebagai Water holding capacity. Selanjutnya, Zone Saturate ( zone jenuh) merupakan zona dengan persebaran air mengisi rongga antar partikel tanah. Pada zona ini ketersediaan airtanah melimpah, dan dimanfaatkan untuk penyediaan air bersih oleh manusia. Zona jenuh dimulai dari water table sampai dengan lapisan impermeable batuan. Kapasitas potensi penyediaan airtanah merupakan hasil penjumlahan dari jumlah air pada zone aerasi dan zone jenuh. Ketersediaan airtanah tergantung dari tingkat infiltrasi dan perkolasi di daerah tangkapan air (recharge area).

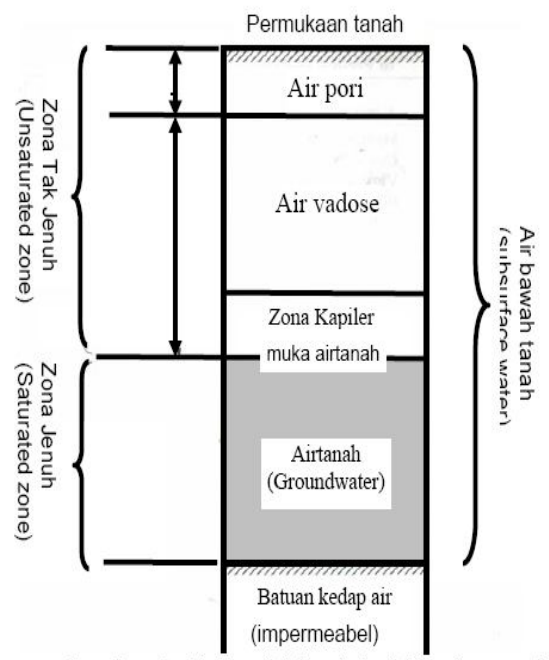

Gambar 1. Skema distribusi air di bawah permukaan

Recharge area di Yogyakarta dipengaruhi oleh kondisi fisik lahan di daerah hulu, dalam hal ini pada daerah lereng Gunungapi Merapi. Merapi merupakan tulang punggung sistem geohidrologi kawasan dataran Jogja dan sekitarnya. Air yang mengalir dari 
tubuhnya bukan hanya untuk masyarakat di lerengnya, tetapi juga untuk masyarakat Kota Jogja dan sekitarnya. Daerah Yogyakarta yang topografinya bervariasi dari lereng Gunungapi Merapi di sisi utara, kemudian ke selatan ada dataran rendah, dan berakhir di daerah pesisir selatan. Di sisi tenggara Kota Yogyakarta terdapat pegunungan batu gamping yang potensi airtanahnya besar tetapi tersembunyi di loronglorong sungai bawah tanah. Setiap daerah memiliki potensi airtanah yang berbeda-beda. Artinya, airtanah tersimpan dalam lapisan yang bervariasi pula. Selaku fungsinya sebagai kawasan resapan air, maka kawasan lereng Selatan Merapi merupakan kawasan lindung bawahan. Perubahan penggunaan lahan ini berdampak pada menurunnya tingkat infiltrasi ke dalam tanah. Akibatnya, kondisi ini mengakibatkan dampak buruk sebagai fungi hidrogeologis kawasan, yaitu fluktuasi posisi muka airtanah dataran Jogja pada saat musim kemarau mengalami penurunan 5 - 10 meter. Kondisi ini bukan hanya karena jumlah pengambilannya yang bertambah, tetapi juga berkurangnya air masukan air permukan.

\section{Tipologi Sistem Akuifer Gunungapi Merapi}

Pengetahuan tentang Geometri keterdapatan airtanah di bawah permukaan dapat menjelaskan tentang karakteristrik dan sifat airtanah. Kondisi dan distribusi sistem akuifer dalam sistem geologi dikontrol oleh faktor litologi, stratigrafi dan struktur dari endapan-endapan geologi. Litologi adalah penyusun secara fisik meliputi komposisi mineral, ukuran butir dan kemas dari endapan-endapan atau batuan yang membentuk sistem geologi. Stratigrafi menggambarkan kondisi geometri dan hubungan umur antar lapisan atau satuan batuan dalam sistem geologi. Sedangkan struktur geologi merupakan bentuk/sifat geometri dari sistem geologi yang diakibatkan deformasi yang terjadi setelah batuan terbentuk. Pada sedimen yang belum terkonsolidasi/ kompak, kontrol yang berperan adalah litologi dan stratigrafi. Pengetahuan akan ketiga faktor di atas memberikan arahan kepada pemahaman karakteristik dan distribusi sistem akuifer (Freeze dan Cherry, 1979). Kesamaan iklim dan kondisi geologi di suatu daerah akan memberikan kesamaan sistem airtanah. Kondisi ini akan berpengaruh terhadap karakter fisika dan kimia serta kualitas airtanah dalam sistem tersebut.

Tipologi system akuifer Gunungapi Merapi adalah Tipologi Sistem Akuifer Endapan Gunung Api. Secara morfologi, gunungapi 
terbagi atas 5 bagian, yaitu daerah Atas, Tengah, Bawah dan Kaki serta dataran Endapan. Pada masing-masing bagian ini, pembentukan dan penyebaran airtanah mempunyai sifat dan karakteristik tertentu.

Keberadaan airtanah di daerah ini umumnya pada batuan yang sangat berpori dan tidak kompak, berselang-seling dengan lapisanlapisan aliran lava yang umumnya kedap air. Hal ini menyebabkan terakumulasinya airtanah yang cukup besar dan muncul sebagai mataair-mataair dengan debit bervariasi.

Selain sistem media pori, potensi airtanah pada daerah ini dijumpai pula pada akuifer- akuifer dengan sistem media rekahan yang banyak dijumpai pada lava. Rekahan tersebut terbentuk oleh kekar-kekar yang terjadi akibat proses pada saat pembekuannya ataupun akibat tektonik/volkanisme. Di beberapa daerah mataair dengan sistem rekahan ini menunjukkan debit yang sangat besar.

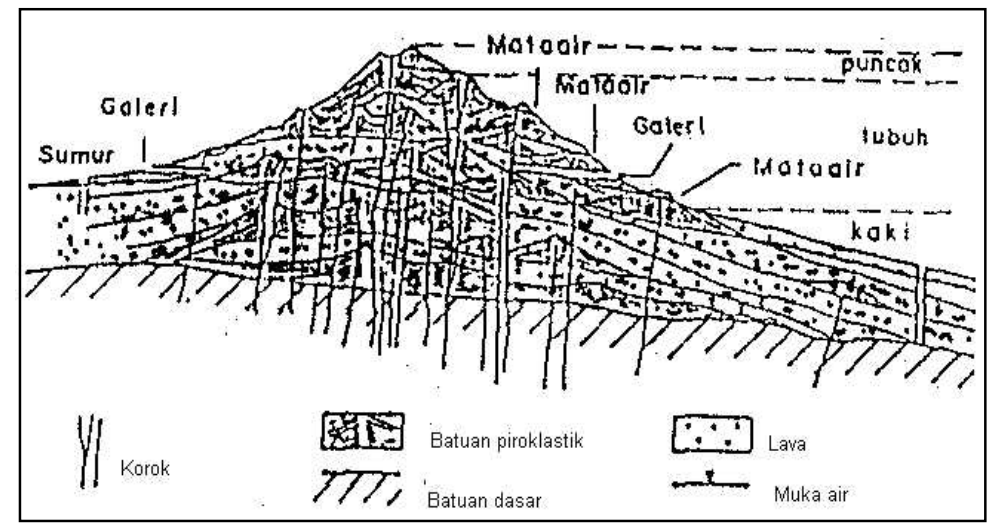

Gambar 2: Tipologi Akuifer Endapan Gunung Api

Kabupaten Sleman memiliki sistem akuifer yang berlapis banyak (multilayer aquifer) yang secara hidrogeologis membentuk suatu Sistem Akuifer Merapi (SAM) dan memiliki sifat-sifat hidrolika relatif sama dan saling berhubungan. Di bagian utara Sistem Akuifer Merapi didasari oleh batuan volkanik Merapi Tua berumur Pleistosen Atas, di bagian timur didasari oleh batuan Tersier Formasi Nglanggran dan Semilir, serta batuan Tersier Formasi Sentolo di bagian barat maupun selatan.

Secara umum airtanah mengalir dari utara ke selatan, dengan pofa aliran yang menyebar membentuk pola radial sentrifugal. Pola 
persebaran tersebut merupakan ciri khas morfologi gunungapi. Zonasi akuifer secara lateral dibagi menjadi 2 bagian, yaitu:

a. Daerah pengisian (recharge area), terletak di bagian lereng atas, lereng tengah dan lereng bawah Gunungapi Merapi. Airtanah berasal dari peresapan air hujan, dan peresapan aliran air sungai maupun aliran irigasi. Daerah resapan merupakan kawasan yang perlu dijaga keasliannya, karena sangat menentukan ketersediaan air pads zona pengeluaran.

b. Daerah pengeluaran (discharge area), meliputi: satuan kakilereng Gunungapi Merapi, dengan gradien ke arah selatan semakin mengecil. Seiring penurunan gradien topografis, diikuti pula penurunan gradien muka airtanah, sehingga semakin ke arah selatan kecepatan aliran airtanah akan semakin menurun.

Ketebalan akuifer secara umum tebal ( $>50$ meter) dan semakin bertambah tebal ke arah selatan, yaitu: di wilayah Ngaglik mencapai 80 meter, di wilayah Bedog dan Karangayam sekitar 140 meter dan di Kota Yogyakarta mencapai 150 meter. Secara vertikal Sistem Akuifer Merapi dibagi menjadi 3 bagian utama, yaitu: akuifer bagian atas, akuifer bagian bawah, dan dasar akuifer. Karakteristik masingmasing akuifer diuraikan sebagai berikut.

a. Akuifer baqian atas, dibentuk oleh Formasi Yogyakarta, dan terletak di bagian utara. Akuifer ini tersusun oleh lava andesit dan endapan breksi volkanik Merapi Tua. Pada beberapa lokasi dijumpai adanyaendapan lahar clan pasir lempungan. Bagian tengah Sistem Akifer Merapi tersusun atas pasir sedang sampai pasir kasar, kerikil dan bongkahan dengan diameter sekitar $0,5 \mathrm{~m}$, serta lensa-lensa andesit dan breksi. Pada bagian selatan tersusun atas pasir halus sampai pasir sedang, lanau pasiran, lempung pasiran, dan kerikil halus. Pada bagian ini jarang dijumpai lensalensa lava maupun breksi volkanik seperti dijumpai pada bagian tengah dan utara. Kedalaman maksimum akuifer mencapai 25 meter.

b. Akuifer baqian bawah, didominasi oleh endapan yang berasal dari Formasi Sleman. Di bagian utara akuifer ini tersusun oleh material pasir kasar, kerikil kasar dan bongkahan, endapan breksi volkanik serta lensa lava andesit. Pada bagian ini dijumpai adanya sisipan tuff kasar, pasir lempungan, dan lempung dengan persebaran setempat. Bagian selatan sistem akuifer ini didominasi oleh pasir halus sampai pasir sedang, kerikil halus, 
pasir lempungan dan lempung pasiran. Ciri akuifer bawah memiliki tingkat produktivitas tinggi dan permeabilitas akuifer sedang sampai tinggi.

c. Dasar akuifer, di bagian utara tersusun atas batuan breksi volkanik dan lava andesit yang sangat kompak dan keras yang berasal dari endapan Merapi Tua. Di bagian tengah dan selatan berupa cekungan yang dibentuk oleh Formasi Sentolo; batuan intrusi di bagian barat dan batuan Tersier dari Formasi Nglanggran dan Semilir.

\section{Pembatasan Penulisan}

Penulisan ini dibatasi pada Kawasan Lereng Gunungapi Merapi bagian selatan sebagai Recharge Area Airtanah; yaitu: wilayah Lereng Atas, Tengah, Bawah, Lereng kaki, Kerucut Anakan dan Kerucut Volkan Merapi. Distribusi Landform dari Recharge area adalah sebagai berikut ini:

1) Lereng Atas volkan, terdistribusi di Kecamatan Pakem, Cangkringan, Turi.

2) Lereng Tengah volkan, terdistribusi di Kecamatan Pakem, Cangkringan, Turi.

3) Lereng Bawah volkan, terdistribusi di Kecamatan Pakem, Cangkringan, Turi.

4) Lereng Kaki volkan, terdistribusi di Kecamatan Pakem, Cangkringan, Turi, Ngemplak, Ngaglik, Sleman, Tempel.

5) Kerucut anakan, terdistribusi di Kecamatan Pakem.

6) Kerucut Volkan, terdistribusi di Kecamatan Pakem.

\section{Sumber dan Analisis Data}

Data diperoleh dari data sekunder tentang kondisi alam fisik wilayah daerah Lereng Gunungapi Merapi Bagian Selatan. Data tersebut adalah :

1) Peta Rupa Bumi Indonesia (RBI)

(Sheet $1408: 244 ; 241 ; 242 ; 223 ; 224 ; 232 ; 214$ )

2) Peta Tematik Digital

(Peta : Landuse, Landcover, Landform, Administratif)

3) Basis Data Sumberdaya Wilayah Kabupaten Sleman (2001)

(Data : Sumberdaya lahan, Sumberdaya Air) 
Tehnik analisis data, merupakan pengolahan data sekunder yang diperoleh dan dilakukan pengukuran dan penghitungan dengan menggunakan teknik analisis data sebagai berikut:

1) Analisis GIS, untuk menentukan Pola distribusi spatial potensi airtanah dengan menggunakan software Arc View 3.2

2) Neraca Keseimbangan Air, menentukan potensi ketersediaan airtanah dengan menggunakan Metode Rasional dan Metode Thornthwhite.

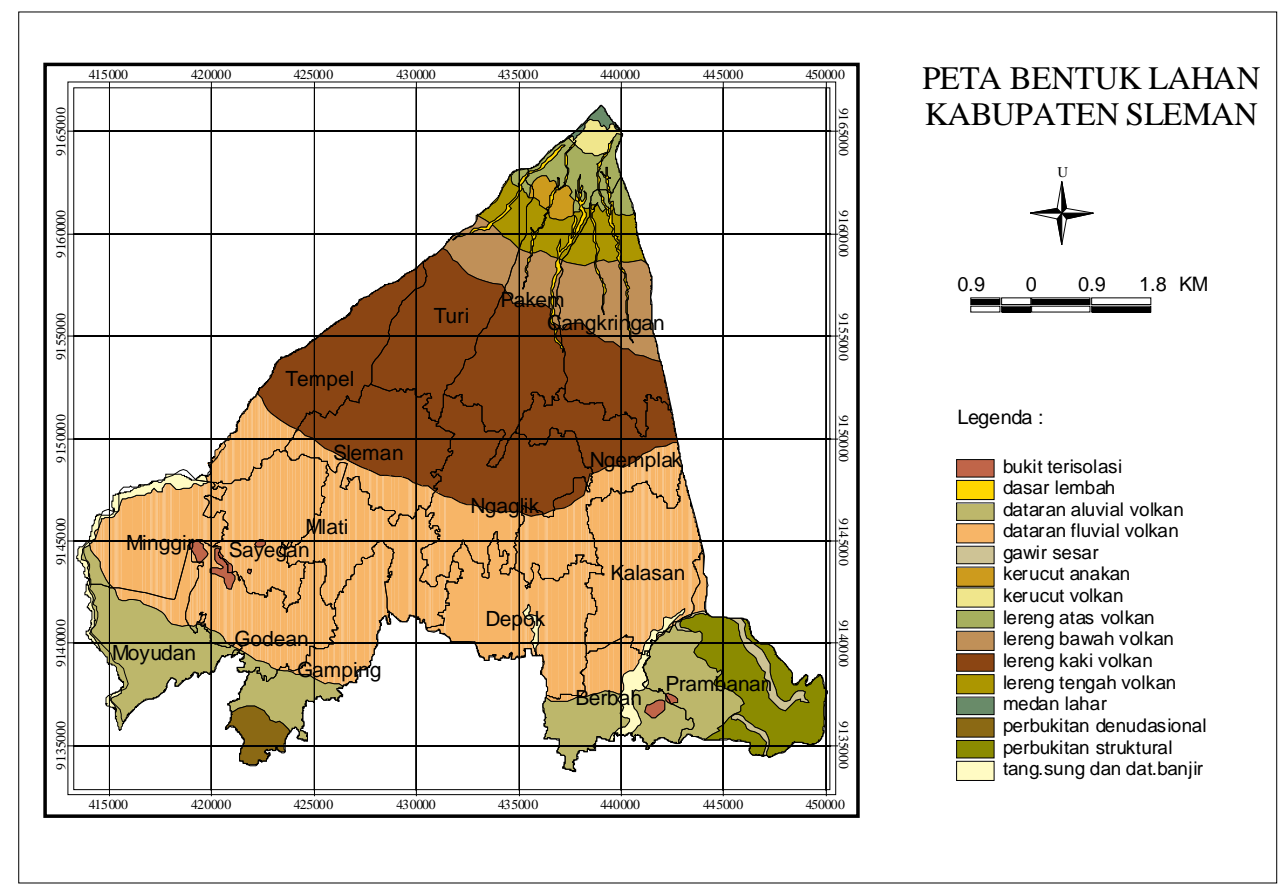

Penggunaan metode dan teknik estimasi jumlah kapasitas air dalam akuifer di Lereng Gunungapi Merapi bagian Selatan digunakan beberapa asumsi dasar, yaitu sebagai berikut ini:

1) Akuifer Gunungapi Merapi bagian selatan relatif homogen.

2) Gradient ketebalan akuifer Gunungapi Merapi bagian selatan bersifat teratur dinamik.

3) Validitas Data tahun 1998 (Data Luas Landuse, RBI) 


\section{Kemampuan Lahan Lereng Gunungapi Merapi Bagian Selatan}

Klasifikasi kemampuan lahan adalah penilaian komponen lahan yang menurut Arsyad (1989) adalah penilaian komponenkomponen lahan secara sistematis dan pengelompokan ke dalam berbagai kategori berdasar sifat-sifat yang merupakan potensi dan penghambat dalam penggunaan lahan. Berdasar Bentuk Lahan, wilayah Lereng Gunungapi Merapi bagian Selatan mempunyai Kelas kemampuan lahan dan arahan penggunaan lahan sebagai berikut:

Tabel 1: Kelas Penggunaan Lahan dan Arahan

Penggunaan Lahan

\begin{tabular}{|c|l|c|c|c|c|}
\hline No & \multicolumn{1}{|c|}{$\begin{array}{c}\text { Satuan } \\
\text { Bentuklahan }\end{array}$} & $\begin{array}{c}\text { Kelas } \\
\text { Kemampuan } \\
\text { lahan }\end{array}$ & $\begin{array}{c}\text { Arahan } \\
\text { Penggunaan } \\
\text { lahan }\end{array}$ & $\begin{array}{c}\text { Penggunaan } \\
\text { lahan sekarang }\end{array}$ & Ketidaksesuaian \\
\hline 1 & Lereng Atas & Volkan & $\begin{array}{c}\text { Hutan } \\
\text { Produksi, } \\
\text { Perkebunan, }\end{array}$ & $\begin{array}{c}\text { Pertanian, } \\
\text { Permukiman, } \\
\text { Perkebunan, } \\
\text { Peternakan, } \\
\text { tambang }\end{array}$ & $\begin{array}{c}\text { Permukiman, } \\
\text { Peternakan, } \\
\text { Tambang } \\
\text { dibatasi }\end{array}$ \\
\hline 2 & Lereng & IV & $\begin{array}{c}\text { Sangat } \\
\text { Terbatas }\end{array}$ & $\begin{array}{c}\text { Pertanian, } \\
\text { Pemukiman, } \\
\text { Tambang }\end{array}$ & Pertambangan \\
Perlu Diatur
\end{tabular}

Sumber: Suratman Woro: 2005.

\section{Analisis Water Storage Capacity Lereng Gunungapi Merapi Bagian Selatan}

Kapasitas potensi penyediaan airtanah (St) merupakan hasil penjumlahan dari jumlah air pada non saturated zone dan saturated 
zone. Perhitungan kapasitas penyimpanan air tiap bentuk lahan dilakukan dengan asumsi dasar:

1) Water Storage Capacity Awal $\left(\mathrm{St}_{0}\right)$ berupa original landuse hutan di kawasan Lereng Gunungapi Merapi bagian selatan; Untuk Non saturated Zone digunakan perhitungan water holding capacity (WHC) dan untuk Saturated Zone digunakan perhitungan water storage berdasarkan porositas tanah dan batuan.

2) Water Storage Capacity Sekarang $\left(\mathrm{St}_{\mathrm{sk}}\right)$ berupa Landuse sekarang; pekarangan, sawah, tegalan, hutan dan lainya; Untuk Non saturated Zone digunakan perhitungan water holding capacity (WHC) dan untuk Saturated Zone digunakan perhitungan water storage berdasarkan porositas tanah dan batuan.

Kapasitas penyimpanan air dalam tanah tidak terlepas dari porositas tanah yang ada dalam wilayah tersebut. Porositas menunjukkan perbandingan volume pori-pori udara antar partikel tanah per volume total tanah. Sehingga dapat dirumuskan sebagai berikut :

$$
\alpha=\frac{v 1}{V} \quad \text { atau } \quad \alpha=\mathrm{Sy}+\mathrm{Sr}
$$

Dengan $S y=\frac{W y}{v 3} x 100 \% \quad$ dan $\quad S r=\frac{W r}{V} \times 100 \%$

Keterangan:

$\alpha=$ porositas

$\mathrm{v} 1$ = volume udara

$\mathrm{Sr}=$ Specific retention

$\mathrm{v} 2$ = volume tanah

$\mathrm{Wy}=$ Volume air yang dapat diambil

Sy $=$ Specific yield

$\mathrm{Wr}=$ Volume air yang tertinggal dalam tanah

Perhitungan kapasitas penyimpanan air tiap bentuk lahan dilakukan dengan perhitungan sebagai berikut ini:

1) Water Storage Capacity pada Non saturated Zone $\left(\mathrm{St}_{1}\right)$

$\mathrm{St}_{1}=\mathrm{SmR} \times$ If $\mathrm{x}$ A $\mathrm{x} \mathrm{h}$

2) Water Storage Capacity pada Saturated Zone $\left(\mathrm{St}_{2}\right)$

$\mathrm{St}_{2}=\mathrm{Sy} \times \mathrm{A} \times \mathrm{h}$

Sehingga Kapasitas penyimpanan air dalam akuifer adalah :

$$
\mathrm{St}=\mathrm{St}_{1}+\mathrm{St}_{2}
$$


Perhitungan pada Non saturated Zone dan Saturated Zone dilakukan pada kondisi keadaan Landuse awal (hutan) dan Landuse sekarang (pekarangan, sawah, tegalan, hutan dan lainnya), sehingga dapat diketahui perbedaan storage air antara keadaan awal $\left(\mathrm{t}_{0}\right)$ dengan keadaan sekarang $\left(\mathrm{t}_{\mathrm{sk}}\right)$, dirumuskan sebagai berikut ini :

$$
\begin{aligned}
\Delta \mathrm{St} & =\sum \mathrm{St}_{0}-\sum \mathrm{St}_{\mathrm{sk}} \\
\Delta \mathrm{St} & =\left(\mathrm{St}_{1}+\mathrm{St}_{2}\right)_{\mathrm{awal}}-\left(\mathrm{St}_{1}+\mathrm{St}_{2}\right)_{\text {sekarang }}
\end{aligned}
$$

$\Delta$ St menunjukkan adanya defisit air berdasarkan perubahan landuse awal dan landuse sekarang.

Konservasi airtanah perlu adanya pengembalian fungsi lereng Gunungapi Merapi sebagai recharge area bagi daerah di bawahnya. Konsep konservasi air pada daerah recharge area adalah dengan memperbesar intersepsi, infiltrasi, dan perkolasi serta memperkecil terjadinya overland flow dengan memperhatikan bebarapa aspek, yaitu:

1) Kemiringan lereng, ketebalan akuifer serta kedalaman water table

2) Tingkat Erosi Permukaan terhadap lahan.

3) Kekuatan lahan menahan massa vegetasi penutup.

Jumlah defisit air awal dan sekarang di Recharge area Lereng Merapi bagian Selatan adalah :

$$
\begin{aligned}
\Delta \mathrm{St}_{0-\mathrm{Sk}} & =\mathrm{St}_{0}-\mathrm{St}_{\mathrm{Sk}} \\
& =(1248,9-941,1) \times \text { juta } \mathrm{m} 3 \\
& =307,8 \text { juta } \mathrm{m}^{3}
\end{aligned}
$$

Jadi Defisit water storage capacity awal dengan sekarang di recharge area lereng Gunungapi Merapi bagian selatan adalah 308 juta $\mathrm{m}^{3}$. 
Tabel 2: Analisis Water Storage Capacity T1 Dan T2 (1980 -2006)

Dalam Recharge Area Aquifer Lereng Gunungapi Merapi

Bagian Selatan Kabupaten Sleman Yogyakarta

\begin{tabular}{|c|c|c|c|c|c|c|c|}
\hline No. & Kec. & Bentuk Lahan & Luas (Ha) & Tekstur & $\begin{array}{l}\text { Rerata } \\
\text { tebal } \\
\text { Akuifer } \\
(\mathrm{m})\end{array}$ & $\begin{array}{c}\text { Max } \\
\text { Storage } \\
\text { Akuifer T1 } \\
\text { (juta m3) }\end{array}$ & $\begin{array}{c}\text { Max } \\
\text { Storage } \\
\text { Akuifer T2 } \\
\text { (juta m3) }\end{array}$ \\
\hline \multirow[t]{2}{*}{1} & Tempel & Lereng Kaki & 2057.7 & \multirow{2}{*}{$\begin{array}{c}\text { Pasir } \\
\text { Sedang } \\
\end{array}$} & 71.8 & 143 & 112.7 \\
\hline & & Dataran Fluvial & 1191.3 & & 115.5 & & \\
\hline \multirow[t]{2}{*}{2} & Sleman & Lereng Kaki & 2125.3 & \multirow{2}{*}{$\begin{array}{c}\text { Pasir } \\
\text { Sedang }\end{array}$} & 71.8 & 165 & 113 \\
\hline & & Dataran Fluvial & 1006.7 & & 115.5 & & \\
\hline \multirow[t]{2}{*}{3} & Ngemplak & Lereng Kaki & 2123.2 & \multirow{2}{*}{$\begin{array}{c}\text { Pasir } \\
\text { Sedang } \\
\end{array}$} & 71.8 & 145.7 & 115.1 \\
\hline & & Dataran Fluvial & 1447.8 & & 115.5 & & \\
\hline \multirow[t]{2}{*}{4} & Ngaglik & Lereng Kaki & 2361 & \multirow{2}{*}{$\begin{array}{c}\text { Pasir } \\
\text { Sedang }\end{array}$} & 71.8 & 176.4 & 128.6 \\
\hline & & Dataran Fluvial & 1491 & & 115.5 & & \\
\hline \multirow[t]{4}{*}{5} & Cangkringan & \begin{tabular}{|l} 
Lereng Kaki \\
\end{tabular} & 1450.8 & \multirow{4}{*}{$\begin{array}{c}18 \% \\
\text { Pasir } \\
\text { Sedang; } \\
72 \% \\
\text { Pasir } \\
\text { Kasar } \\
\end{array}$} & 71.8 & 223.3 & 170.6 \\
\hline & & Lereng Bawah & 1674.2 & & 47 & & \\
\hline & & \begin{tabular}{|l} 
Lereng Tengah \\
\end{tabular} & 1227.6 & & 36 & & \\
\hline & & Lereng Atas & 446.4 & & 25 & & \\
\hline \multirow[t]{4}{*}{6} & Turi & Lereng Kaki & 1846.7 & \multirow{4}{*}{$\begin{array}{c}88 \% \\
\text { Pasir } \\
\text { Sedang; } \\
12 \% \\
\text { Pasir } \\
\text { Kasar }\end{array}$} & 71.8 & 222.7 & 175.8 \\
\hline & & Lereng Bawah & 1231.2 & & 47 & & \\
\hline & & Lereng Tengah & 861.8 & & 36 & & \\
\hline & & Lereng Atas & 369.3 & & 25 & & \\
\hline \multirow[t]{7}{*}{7} & Pakem & Lereng Kaki & 1289.4 & \multirow{6}{*}{$\begin{array}{c}40 \% \\
\text { Pasir } \\
\text { sedang; } \\
60 \% \\
\text { Pasir } \\
\text { Kasar } \\
\end{array}$} & 71.8 & 172.8 & 125.3 \\
\hline & & Lereng Bawah & 653.3 & & 47 & & \\
\hline & & Lereng Tengah & 722.1 & & 36 & & \\
\hline & & Lereng Atas & 945.6 & & 25 & & \\
\hline & & Kerucut Anakan & 343.8 & & 28.8 & & \\
\hline & & Kerucut Vulkan & 429.8 & & & & \\
\hline & \multicolumn{5}{|c|}{ JUMLAH WATER STORAGE CAPACITY T1 dan T2 } & 1248.9 & 941.1 \\
\hline
\end{tabular}

Sumber: Hasil Perhitungan, 2007.

\section{Alternatif Usaha Konservasi Air Lereng Gunungapi Merapi}

\section{Bagian Selatan}

Untuk menanggulangi debit air di Recharge area Lereng Gunungapi Merapi bagian Selatan dilakukan bebarapa alternatif konservasi air, yaitu sebagai berikut ini:

1) Metode Fisik Mekanik

a. Pembuatan Sumur Resapan

b. Pembuatan Teras

c. Pembuatan Situ (embung) 
2) Metode Vegetatif

Alternatif dalam perhitungan konservasi air pada recharge area Lereng Gunungapi Merapi bagian selatan dapat dijelaskan sebagai berikut:

1) Metode Fisik Mekanik

a. Pembuatan Sumur Resapan

Perhitungan jumlah air yang diresapkan dalam tanah dengan sumur resapan adalah:

$\mathrm{V} \quad=\mathrm{A} \times \mathrm{C} \times(\mathrm{rP}-\mathrm{rEP})$

Keterangan :

$\mathrm{V}=$ Volum air yang teresapkan dalam tanah

$\mathrm{C} \quad=$ Index resapan air

$\mathrm{A}=$ Luas Wilayah resapan

$\mathrm{rP} \quad=$ rerata presipitasi tahunan

$\mathrm{rEP} \quad=$ rerata evapotranspirasi tahunan

dengan rEP merupakan rerata evapotranspirasi tahunan yang dihitung berdasarkan evapotranspirasi bulanan (PEx) dan diketahui suhu bulanan (tn), maka dapat diketahui dengan beberapa persamaan sebagai berikut :

dimana :

$$
P E x=16\left(\frac{10 t}{j}\right)^{a}
$$

$$
j=0,09 \mathrm{tn}^{\frac{3}{2}} \quad \text { dan } \quad J=\sum_{1}^{12} j \quad \text { dan } \quad a=0,016 J+0,5
$$

Tabel 3: Presipitasi dan Evapotranspirasi rata-rata Kabupaten Sleman, DIY (1989-1998)

\begin{tabular}{|l|r|r|}
\hline Kecamatan & rP (mm/th) & rEP $(\mathbf{m m} / \mathbf{t h})$ \\
\hline Tempel & 2449.4 & 996.6 \\
\hline Sleman & 2568.0 & 999.7 \\
\hline Ngemplak & 2097.1 & 1001.3 \\
\hline Ngaglik & 2330.8 & 1006.0 \\
\hline Cangkringan & 2304.4 & 913.4 \\
\hline Turi & 3689.0 & 926.7 \\
\hline Pakem & 2440.5 & 910.0 \\
\hline Rata-rata & $\mathbf{2 5 5 4 . 2}$ & $\mathbf{9 6 4 . 8}$ \\
\hline
\end{tabular}

Sumber: Hasil Perhitungan, 2007. 
Perhitungan jumlah air yang diresapkan dalam tanah dengan sumur resapan daerah Pekarangan pada recharge area Lereng Gunungapi Merapi bagian selatan adalah: $\left(\sum \mathrm{A}=7713 \mathrm{Ha}\right.$; $\mathrm{rP}$ $=2554,2 \mathrm{~mm} / \mathrm{th} ; \mathrm{rEP}=964,8 \mathrm{~mm} / \mathrm{th}$ )

$$
\begin{aligned}
\mathrm{V} & =\mathrm{A} \times \mathrm{C} \times(\mathrm{rP}-\mathrm{rEP}) \\
& =77.130 .000 \times 0,95 \times(2,554-(90 \% \times 0,965)) \\
\mathrm{V} & =123,5 \text { juta } \mathrm{m}^{3} / \mathrm{th}
\end{aligned}
$$

Jadi volume air yang dapat diresapkan melalui sumur resapan pada lahan pekarangan seluas 7713 ha adalah $123,5 \mathrm{juta}^{3} /$ th.

b. Pembuatan Teras

Pembuatan Teras pada Lahan Pertanian basah Kelas II - IV yang mempunyai kemiringan Lereng $<15 \%$; terdapat di Kecamatan Pakem dan Ngaglik $\left(\sum \mathrm{A}=3718 \mathrm{Ha}\right)$ maka jumlah air yang dapat diresapkan pada pertanian basah adalah :

$$
\begin{aligned}
\mathrm{V} & =\mathrm{A} \times \mathrm{C} \times(\mathrm{rP}-\mathrm{rEP}) \\
& =3.718 .000 \times 0,75 \times(2,554-0,965) \\
\mathrm{V} & =44,3 \text { juta } \mathrm{m}^{3} / \mathrm{th}
\end{aligned}
$$

Jadi volume air yang dapat diresapkan melalui teras pada lahan pertanian seluas 3718 ha adalah 44,3 juta $\mathrm{m}^{3} /$ th

c. Pembuatan Situ (embung)

Pembuatan Situ/ Embung pada Tegalan $\left(\sum \mathrm{A}=3232 \mathrm{Ha}\right)$

$$
\begin{aligned}
\mathrm{V} & =\mathrm{A} \times \mathrm{C} \times(\mathrm{rP}-\mathrm{rEP}) \\
\mathrm{V} & =3.232 .000 \times 0,95 \times(2,554-0,965) \\
& =48,8 \text { juta } \mathrm{m} 3 / \mathrm{th}
\end{aligned}
$$

Jadi volume air yang dapat diresapkan melalui Situ (embung) pada lahan pertanian seluas 3232 ha adalah 44,8 juta $\mathrm{m}^{3} /$ th

2) Metode Vegetatif

Menambah kuantitas \& kualitas Landcover vegetation:

» Memanfaatkan $50 \%$ Lahan Lain-lain untuk Greenbelt ( $\sum \mathrm{A}=$ $1568 \mathrm{Ha})$, maka jumlah air yang dapat diresapkan adalah:

$$
\begin{aligned}
\mathrm{V} & =\mathrm{A} \times \mathrm{C} \times(\mathrm{rP}-\mathrm{rEP}) \\
& =1.568 .000 \times 0,9 \times(2,554-0,965) \\
\mathrm{V} & =22,4 \text { juta } \mathrm{m} 3 / \mathrm{th}
\end{aligned}
$$


Jadi volume air yang dapat diresapkan melalui green belt (hutan) pada lahan lain-lain seluas 1568 ha adalah 22,4 juta $\mathrm{m}^{3} /$ th.

Jadi Efisiensi yang dapat dilakukan untuk mensikapi defisit airtanah pada recharge area lereng Gunungapi Merapi bagian selatan adalah :

Efisiensi $(\mathrm{y})=\mathrm{Jml}$. Volum Konservasi Air-Defisit air $\left(\Delta \mathrm{St}_{0-\mathrm{Sk}}\right)$

$$
\begin{aligned}
& =\{(123,5+44,3+44,8+22,4)-307,8\} . \text { juta } \mathrm{m}^{3} / \text { th } \\
& =-72,8 \text { juta } \mathrm{m}^{3} / \text { th }
\end{aligned}
$$

Jadi Usaha konservasi lahan yang dilakukan belum dapat mengembalikan jumlah resapan air ke dalam tanah seperti keadaan awal (hutan) sejumlah 72,8 juta $\mathrm{m}^{3} /$ th; akan tetapi sudah melakukan efisiensi peresapan air sejumlah 235 juta $\mathrm{m}^{3} / \mathrm{th}$.

\section{Penutup}

a. Penyusutan Water Storage Capacity pada dataran Sedimen Merapi disebabkan oleh:

1) Perubahan Landuse serta Landcover wilayah Recharge Area.

2) Penggundulan hutan oleh manusia.

3) Pertumbuhan Penduduk yang berakibat pada peningkatan jumlah kebutuhan airtanah $>>$ memperbesar volume pengambilan airtanah

4) Pengolahan Lahan tidak sesuai dengan Kelas Kemampuan Lahannya

5) Pengurangan volume akuifer karena pertambangan yang tidak ramah lingkungan

b. Rekomendasi Konservasi Air

1) Metode Fisik Mekanik

» Pembuatan Sumur Resapan pada Pekarangan efiensi = 123,5 juta $\mathrm{m} 3 /$ th

» Pembuatan Teras pada Lahan Pertanian basah Kelas II - IV $=44,3$ juta $\mathrm{m} 3 /$ th $\quad$ yang terdapat di Pakem dan Ngaglik

» Pembuatan Situ/ Embung pada Tegalan $=48,8$ juta $\mathrm{m} 3 / \mathrm{th}$

2) Metode Vegetatif

» Memanfaatkan $50 \%$ Lahan Lain-lain untuk Greenbelt = 22,4 juta $\mathrm{m} 3 /$ th

Jumlah Efisiensi Water Storage Capacity $=235$ juta $\mathrm{m} 3 /$ th 


\section{Daftar Pustaka}

, 2001, Penyusunan Basis Data Sumber Daya Wilayah di

Kabupaten Sleman, Bappeda Kab Sleman- Fakultas Geografi UGM, Yogyakarta. 2000, Praktikum Hidrogeologi Umum, ITB, Bandung.

Darmakusuma D, 2006, "Metode Thornthwaite \& Matter" serta "Konservasi Air Sumur Resapan", Universitas Gadjah Mada, Yogyakarta.

Ig. Setyawan Purnama, 2000, Bahan Ajar Geohidrologi, Universitas Gadjah Mada, Yogyakarta.

Suratman Woro, 2005, Klasifikasi Lahan untuk Perencanaan

Penggunaan Lahan di Kabupaten Sleman Daerah Istimewa

Yogyakarta, Forum Perencanaan Pembangunan - Edisi Khusus, Januari 2005.

Tood, D.K, 1984, Groundwater Hydrology, $2^{\text {nd }}$ ed, John Willey and Sons, New York, USA.

Wilson, E. M, 1993, Hidrologi Teknik, ITB Press, Bandung. 